\title{
TRANSFORMING MALAYSIA TOWARDS AN INNOVATION-LED ECONOMY BY LEVERAGING ON INNOVATIVE HUMAN CAPITAL
}

\author{
Hasliza Abdul Halim; Noor Hazlina Ahmad \\ School of Management, Universiti Sains Malaysia \\ 11800 Penang, Malaysia \\ haslizahalim@usm.my
}

\begin{abstract}
Fostering "pioneering minds" is extremely important especially in the effort to shift Malaysia towards an innovation-led economy. The Malaysian government is confident of achieving this transformation agenda provided that the human capital is leveraged in ensuring innovation at the highest level. The primary aim of this research is to investigate the predictors that could nurture the "pioneering minds" by exploring the innovative performance of human capital from the perspective of social embedment and pro-innovativeness organisational architecture which could subsequently lead to excellent organisational performance. This research contributes to the existing literature on human capital and innovation by having better understanding on the specific factors that nurture the "pioneering minds" which are crucial for innovative performance.
\end{abstract}

Keywords: innovation, human capital, pioneering minds, innovation-led economy, Malaysia

\begin{abstract}
ABSTRAK
Pembinaan "pikiran perintis" sangatlah penting terutama dalam upaya untuk membawa Malaysia menuju ekonomi menuju-inovasi. Pemerintah Malaysia yakin untuk mencapai agenda transformasi ini asalkan modal manusia diperkuat dalam memastikan inovasi di tingkat tertinggi. Tujuan utama penelitian ini adalah untuk mengetahui prediktor yang dapat mengasah "pikiran perintis" dengan menjelajahi kinerja inovatif dari modal manusia dari perspektif penyisipan sosial dan pro-inovasi arsitektur organisasi yang kemudian dapat menyebabkan kinerja organisasi yang unggul. Penelitian ini memberikan kontribusi terhadap literatur yang ada pada modal manusia dan inovasi dengan memiliki pemahaman yang lebih baik pada faktor-faktor tertentu yang memelihara "pikiran perintis" yang sangat penting untuk kinerja inovatif.
\end{abstract}

Kata kunci: inovasi, modal manusia, pikiran perintis, ekonomi menuju-inovasi, Malaysia 


\section{INTRODUCTION}

Malaysia needs a paradigm shift from a knowledge-based economy to innovation-centred in order to stand in the same row with advanced nations as propagated in the New Economic Model Agenda. According to Prime Minister Datuk Seri Najib Tun Razak, moving towards this economy is crucial especially in efforts to integrate the economy with the global economic network. Malaysia needs to continue to bring changes to the economy in order to move towards innovation-led economy. The three main features are creativity, innovation value and high skills. To achieve such noble endeavour, Malaysia has no option but to nurture "pioneering minds" - to simply put, Malaysia is in dire needs of human capital that are innovative, creative and proactive.

Against this backdrop, the National Economic Advisory (2010) has outlined several strategic plans to transform Malaysia's economy by focusing on strengthening and intensifying human capital development. Human capital needs to be equipped with necessary competencies and entrepreneurial activities to ensure that the private sector is the vanguard of economic development. In nurturing 'pioneering minds", the human capital approach could be leveraged by certain dimensions that could create new knowledge. Although human capital may be the origin of all knowledge, learning requires that individuals exchange and share insights and knowledge, which represent social embedment. Additionally, organisational architecture that is pro-innovativeness should be designed in promoting the development of human capital. The dimensions such as management support, work discretion, rewards, time availability and risk taking could foster human capital to induce innovativeness. Therefore, this research aims at investigating predictors that could nurture the "pioneering minds" by exploring the innovative performance of human capital by leveraging the social embedment and proinnovativeness organisational architecture which lead to excellent organisational performance. This research contributes to the existing literature on human capital and innovation by having better understanding on the specific factors that nurture the "pioneering minds" which are crucial for innovative performance.

Fostering "pioneering minds" is extremely important especially in the effort to shift Malaysia towards innovation-centred economy. The Malaysian government is confident of achieving the target provided that the human capital is leveraged in ensuring innovation at the highest level. Human capital, conceptualized as the knowledge and knowing capability of an organisation represents one of the most relevant antecedents of innovation, which has become the fundamental for achieving competitive advantage (Martinez-Ros and Salas-Fumas, 2004; Zhou, 2006). The importance of human capital for innovation has attracted researchers interested in examining its factors by which it enhances the innovative capabilities and performance of the organisations. In fact, the changes that are taken place in today's business landscape have exerted pressure for organisations to compete towards organisational sustainability by providing high quality and innovative products and services. In order to achieve this, organisations need to emphasise on boosting and enhancing intrapreneurial spirit among employees to sustain in longer run. In line with this, it is accepted that organisation's innovation capabilities are more closely linked to their intellectual capital to their fixed assets (Subramaniam and Youndt, 2005). Some evidence suggest that an organisation's human capital is positively associated with its innovative capability (Alegre, Lapiedra and Chiva, 2006; McKelvie and Davidsson, 2006) and many studies have attempted to determine the direct effect of human capital on innovation. However, despite the role that human capital is assumed to have on innovation, few studies have considered human capital as a variable that mediates the effects of other variables on innovation. Therefore, this research is hoped to have a better understanding of how human capital i.e. highly knowledgeable and skilled employees will be leveraged by different variables such as social embedment and pro-innovativeness organisational architecture in order to achieve innovative performance as well as the organisational performance. 
In Malaysia, the study of innovation is becoming prevalent and the Malaysian government has taken various measures to face the stiff competition and one of the approaches is via invigorating intrapreneurial spirit among the employees to enhance productivity, innovativeness and job performance. As reported in the Economic Transformation Programme Report, Malaysia's strategic plan to transform its economy focuses on strengthening and escalating human capital development (National Economic Advisory, 2010). As clearly highlighted by the Prime Minister of Malaysia, Dato Seri Najib Tun Razak, Malaysia aspires to reach the highest standards with regard to the skills, knowledge and abilities of its human capital as well as to foster entrepreneurial spirit especially in the innovation-centred economy. Nevertheless, as for Malaysia, the declining trend in the ranking of Global Competitiveness Index, from $21^{\text {st }}$ place in year 2009 to $26^{\text {th }}$ in year 2011 (World Economic Forum, 2010), is a worrying phenomenon. A mechanism to rectify this situation is to nurture "pioneering minds" in fostering innovativeness and entrepreneurship spirit among Malaysia workforce to enhance productivity and performance.

Malaysia government has started to set the foundation for the knowledge-based economy in the mid-1990s, among others, with the launching of the National IT Agenda and the Multimedia Super Corridor (MSC). The knowledge-based economy will provide the platform to sustain a rapid rate of economic growth and enhance international competitiveness so as to achieve the objectives of Vision 2020. Nevertheless with the current situation that are uncertain and dynamic, Malaysia needs to encourage "pioneering minds" among the human resources- to be innovative, creative and proactive in order to move towards innovation-centred economy. Malaysia has to strengthen its capability to innovate, adapt and create indigenous technology, design, develop and market new products. Furthermore, the government also has granted the "Strategic Knowledge-based Status" to organisations that have potential to generate knowledge content, high value-added operations, usage of high technology, and a large number of knowledge workers and posses a corporate knowledge-based master plan. In brief, Malaysia government has put an effort and continuous investment in its human capital to enhance technical skills, proactiveness, creativity and innovativeness to drive the knowledge-based and innovation-centred economy. Malaysia now has moved towards a sustainable economy, and has shifted the agricultural based production based economy to k-based economy to innovation-centred economy where knowledge, "know-how" and innovativeness become the main drivers for economic growth (MOSTI, 2010).

It is without doubt that the efforts to boost organisations' competitiveness and success would have significant impact on the overall economy of the nation. In line with the Malaysian government aspiration to transform its economy by fostering innovative performance via innovative human capital, the study on innovation and human capital warrants significant attention. Previous studies have investigated the relationship between innovation and human capital (Alegre, Lapiedra and Chive, 2006; McKelvie and Davidsson, 2006), however, despite the role that human capital is assumed to have on innovation, very limited studies have considered the factors that could nurture the "pioneering minds" that is to capture on innovative human capital that are able to drive innovative performance. Besides, the role of human capital as a variable that mediates the effects of other variables on innovation also need to be examined.. Taking this into consideration is crucial because it would help the researchers to better understand the factors associated with innovative human capital which in turn could improve innovative capability and organisational performance. In this sense, the "pioneering minds" could be achieved by leveraging the innovation of human capital through social embedment and pro-innovativeness organisational structure.

Given that innovation is essentially an exercise in collaboration, social embedment plays a key role both directly improving human capital and stressing its effects on innovation. Hence, improving individual knowledge and creating the conditions for sharing it are issues that deserve attention. On top of that, the organisational architecture that support innovativeness via intrapreneurial activities, as an internal climate factor, could help to foster innovative human capital (Alpkan, Bulut, Gunday, Ulusoy and Kilic; 2010). For instance, organisational architecture that pro-innovativeness which refers 
to a suitable organisational setting in which intrapreneurs may easily access to necessarily organisational resources and conditions to develop and implement innovative ideas and projects may encourage the overall organisational innovativeness (Raisch and Birkinshaw, 2008). Based on this, it is worth to investigate their combine effect on innovative human capital and innovative performance.

As the above discussion suggests, there is still much more that needs to be unearthed about nurturing "pioneering minds" that could assist in reaching innovation performance at the highest level. The scope for the development of this promising field of research should examine the following issues which are translated into the objectives of this research, as such, this study embarks on the following objectives: (1) to assess the direct relationship between social embedment (i.e. relational and structural) and innovative human capital; (2) to assess the direct relationship between proinnovativeness organisational architecture ( management support, free time, work discretion, reward and risk taking) on innovative human capital; (3) to recommend a conducive ecosystem in nurturing "pioneering minds" among the human resources in Malaysia.

\section{DISCUSSION}

\section{Innovative Human Capital and Innovation}

Previous research has identified human resources (HR) as important sources of innovation and competitiveness - but not all employees have strategic value. Only HR that are valuable, rare, unique, and organised can provide a competitive advantage. Other employees who perform secondary, repetitive tasks are not generating value (Barney and Wright, 1998). In other words, human capital is defined as the set of knowledge, skills and abilities possesses by employed workers (Subramaniam and Youndt, 2005). This perspective has crucial implications for research in HRM and is compatible with both the resource based view of the organisation and the knowledge-based view. According to Boxall (1996), organisations could generate human capital by recruiting and retaining outstanding people and the HR must be scarce and inimitable and their knowledge, skills must also generate value for the customer (Barney, 1991; Collis and Montgomery).

Considering the human capital approach, the value, uniqueness, creativity, innovativeness and proactiveness are the most relevant features for innovation (De Jong \& Wennekers, 2008). Since the knowledge possesses by an organisation's personnel is closely connected to its products and services, it is clear that an organisation's ability to produce new products and otherwise extend its organisational capabilities is linked to its human capital (McKelvie and Davidsson, 2006). In this case, the most distinctive and inimitable resource available to organisations is embodied knowledge, that enables organisations to manipulate and transform organisational resources effectively (Foss, 2007) and play an essential role in the organisations' ability to innovate (Galunic and Rodan, 1998). Innovation can be applied in three different ways (Kimberly and Evanisko, 1981). First, innovation can be seen as a discrete element that includes the development of products or services. Second, innovation can be considered as a process itself. Finally, there is a notion of innovation an organisational capability (innovativeness and/or innovative capability).

These assumptions raise issues on which characteristics of knowledge enable innovation. This is because creative people must deal with novel, fresh and ambiguous problems, they tend to display strong, valuable and irreplaceable knowledge and skills (Mumford, 2000). These conditions can only be produced by innovative human capital, which is positively associated with innovations. Employees with abilities are willing to experiment and apply new knowledge (Taggar, 2002). Moreover, previous research on innovative activity has identified the importance of individual expertise and knowledge, which allows employees to generate novel ideas and produce innovation (Anand, Gardner and Morris, 
2007). Nevertheless, while valuable knowledge is a perquisite for innovation, knowledge itself cannot develop new products. R\&D departments not only exploit the human capital but also require creativity, unique knowledge, social embedment and organisational support to foster innovations.

\section{Social Embedment and Innovative Human Capital}

Social embedment has been conceptualised as the sum of the actual and potential resources embedded within, available through and derived from networks of relationships possessed by an individual or social unit (Cabello-Medina et al, 2011). Spender (1996) uses the term 'collective knowledge' which is tacit and situated in a social dimension and is the most difficult aspect to mange and measure. According to Nahapiet and Goshal (1998) there are two types of social embedment. First is the structural embedment which includes the pattern of relationships among actors and the existence of network ties and configuration in terms of density, connectivity and hierarchy, besides other aspects. Second, is the relational embedment which relates to the type of relationships that people develop among themselves over the time. This includes aspects of relationships that influence people's behaviour, such as friendship, trust and respect. Social embedment affects innovation through its effect on human capital. The idea is supported by the research on innovation, which suggests that the development of new products and services results not only from individual effort but also from the creative cooperation at the social level (Leonard and Sensiper, 1998). As a result, social embedment and innovative human capital are not independent variables, rather they interact to improve innovative performance.

According to Adler and Kwon (2002), high levels of social embedment can enhance skills and capabilities of individuals. Social embedment facilitates access to broader sources of information and improves information's quality, relevance and timeliness. These situations allow individuals to enhance their knowledge through everyday interaction with colleagues. In this manner, the inimitable value of human capital can be enhanced by social relations. In summary, the individuals' human capital can be more innovative, valuable and unique by ways of interaction and networking with other people (Reed et al. 2006).

\section{Pro-Innovativeness Organisational Architecture and Innovative Human Capital}

The necessity of creating an inner environment that is conducive to internal entrepreneurship and individual commitment to sustainable corporate innovativeness has already been mentioned in the previous literature (e.g. Rothwell, 1975). An organisation-wide entrepreneurial spirit to cope with and benefit from rapidly changing market place conditions would be possible if a suitable internal support climate is established, where intrapreneurs engage in opportunity-seeking entrepreneurial behaviours (Jeong et al., 2006). Intrapreneurship or entrepreneurship within existing organisations refers to employee initiatives in an organisation to start undertake something new although he or she is not being asked to do so.

A suitable organisational milieu for intrapreneurial activities to flourish innovative human capital requires behavioural patterns for pioneering innovative ideas in their products, operational and managerial processes, structures and markets (Alpkan et al., 2010). According to De Jong \& Wennekers, 2008), there are several important elements on how to establish a suitable environment and organisational architecture that focus on innovation for intrapreneurship. These elements include management support for promoting and encouraging innovative human capital in generating new business ideas, allocation of free time, convenience organisational structure to promote innovative human capital, appropriate use of incentives and rewards and tolerance for risk taking.

It has been stressed that organisation should capitalize on their employees' ability to innovate in order to transform the organisation to be more competitive (De Jong \& Hartog, 2007). Therefore, in 
an organisation, the workforce could play a vital role in the innovation process by demonstrating the idea-generation behaviour via efforts such as persuading or selling ideas to others and devoting to developing testing and commercialising the ideas.

\section{Proposed Conceptual Framework}

It is noted that all innovation is premised on a single condition: organisations must possess innovative human capital that are valuable, unique, proactive, creative and innovative. By combining these requirements associated to social embedment and pro-innovativeness organisational architecture in the entrepreneurial activities, the framework (Figure 1) which is based on the development of a type of human capital necessary for innovation will be promoted.

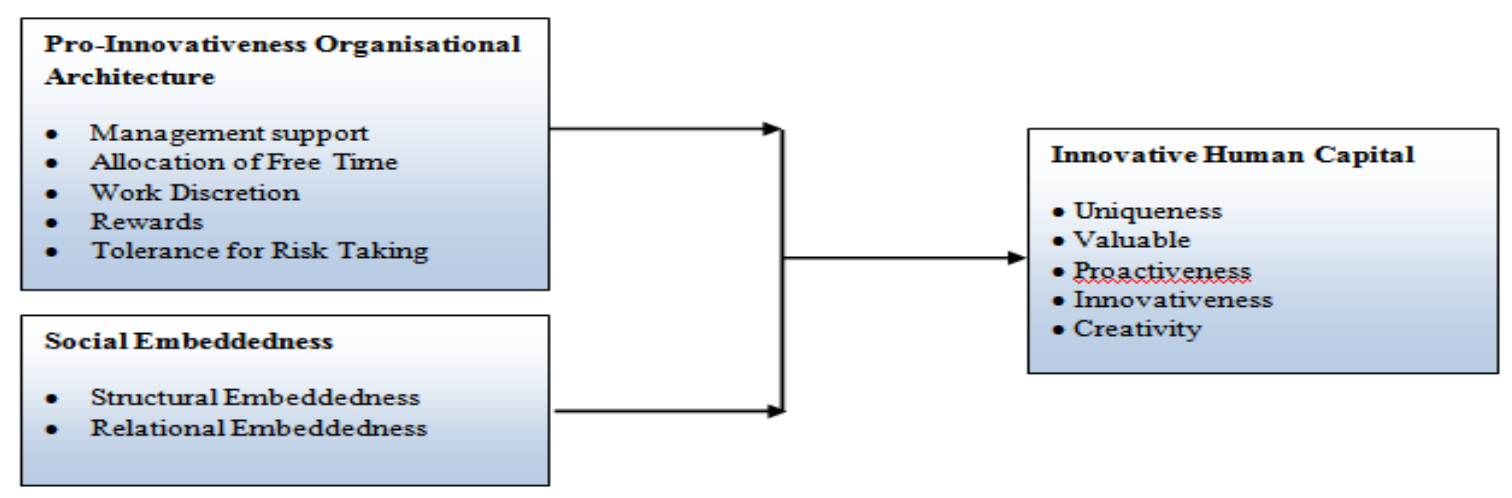

Figure 1. Conceptual framework.

Based on the conceptual framework advanced for this research, the hypotheses conjectured for further empirical testing are as follow:

H1 : Social embedment (structural and relational) will have a positive impact on innovative human capital (unique, valuable, proactive, innovative and creative).

H2 : Pro-Innovativeness Organisational Architecture (management support, free time, work, rewards and risk taking) will have a positive impact on innovative human capital (unique, valuable, proactive, innovative and creative).

\section{CONCLUSION}

It is certain that good research in the area of innovative human capital and innovation will contribute to the existing literature on strategic HRM, knowledge management and business innovation. Empirical research is required in understanding the concept of "pioneering minds" that is to provide a better description of the influence exerted by social embedment and pro-innovativeness organisational architecture on innovative human capital. In this sense, the understanding of the direct and combined effects on innovative performance will add to the body of knowledge in strategic HRM literature. In other words, to nurture "pioneering minds" is simply to understand that the innovative human capital should capture the elements of valuable, uniqueness, pro-activeness, creativity and innovativeness and this can only be achieved by leveraging and enhancing through social embedment and pro-innovativeness organisational architecture for entrepreneurial activities. 
This is even more important in the context of Malaysia as the Government has envisaged transforming Malaysia from a knowledge-based economy to innovation-centred economy by leveraging on the productivity, innovativeness and participation of all in the economic activity. Insights obtained from this research will assist organisations to achieve competitiveness and sustain in the dynamic business environment by investing in innovative human capital. If the innovative performance in an organisation is low, then the quality of human resources should be increased. By embracing the element of social embedment and establish an environment that pro-innovation, the innovative human capital could be enhanced and lead to a major jump in innovative performance.

Policy makers will be able to better understand the issues of innovative human capital and innovation and to provide support for organisations in their effort to stimulate innovative capability via innovative human resources. In realising the transformation of Malaysia's economy, the private sectors should foster entrepreneurial behaviours among the workforce to boost creativity and innovativeness and subsequently achieve organisational performance and competitiveness.

\section{REFERENCES}

Adler, P. S. and Kwon, S.W. (2002). Social capital: prospects for a new concept. The Academy of Management Review, 27 (1), 17-40.

Alegre, J., Lapiedra, R. and Chiva, R. (2006). A measurement scale for product innovation performance. European Journal of Innovation Management, 9, 333-346.

Alpkan, L., Bulut, C., Günday,G., Ulusoy, G. and Kilic, K. (2010). Organizational support for intrapreneurship and its interaction with human capital to enhance innovative performance. Management Decision, 48 (5), 732-755.

Anand, N., Gardner, H. K. and Morris, T. (2007). Knowledge based innovation: emergence and embedding of new practice areas in management consulting firms, Academy of Management Journal, 50, 406-428.

Barney, J. B. (1991). Firm resource and sustained competitive advantage. Journal of Management, 17, 99-120.

Barney, J. B. and Wright, P. M. (1998). On becoming a strategic partner: the role of human resource in gaining competitive advantage. Human Resource Management, 37, 31-46.

Boxall. P. (1996). The strategic HRM debate and the resource based view of the firm. Human Resource Management Journal, 6, 59-75.

Cabello-Medina, C., Carmona-Lavado, A., Pérez-Luño, A. and Cuevas-Rodríguez, G. (2011). Do best and worst innovation performance companies differ in terms of intellectual capital, knowledge and radicalness? African Journal of Business Management, 5 (28), 11450-11466.

Collis, D. and Montgomery, C. (1995). Competing on resource: strategy in the 1990s. Harvard Business Review, 73, 118-128.

De Jong, J. and Hartog, D. N. D (2007). How leaders influence employees' innovative behaviour. European Journal of Innovation Management, 10 (1), 41-64. 
De Jong, J. and Wennekers, S. (2008). Intrapreneurship: conceptualizing entrepreneurial employee behaviour. Scales Research Reports H200802, EIM Business and Policy Research.

Foss, N. J. (2007). The emerging knowledge governance approach: challenges and characteristics. Organization, 14, 29-52.

Galunic, C. and Rodan, S. (1998). Resource recombinations in the firm: knowledge structures and the potential for Schumpeterian innovation. Strategic Management Journal, 19, 1193-1201.

Jeong, I., Pae, J.H. and Zhou, D. (2006). Antecedents and consequences of the strategic orientations in new product development: the case of Chinese manufacturers. Industrial Marketing Management, 35, 348-358.

Kimberly, J. R. and Evanisko, M. J. (1981). Organisational innovation: the influence of individual, organizational and contextual factors on hospital adoption of technological and administrative innovations. Academy of Management Journal, 24, 689-713.

Leonard, D. and Sensiper, S. (1998). The role of tacit knowledge in group innovation. California Management Review, 40 (3), 112-132.

McKelvie, A. and Davidsson, P. (2006). From resource base to dynamic capabilities: an investigation of new firms. British Journal of Management, 20, 63-80.

Mumford, M. (2000). Managing creative people: strategies and tactics for innovation. Human Resource Management Review, 10, 313-351.

Nahapiet, J. and Ghoshal, S. (1998). Social capital, intellectual capital, and the organizational advantage. Academy of Management Review, 23, 242-266.

National Economic Advisory. (2010). Economic Transformation Programme Report. Retrieved September 2011, from http://www.neac.gov.my/node/80.

Raisch, S. and Birkinshaw, J. (2008). Organizational ambidexterity: antecedents, outcomes, and moderators. Journal of Management, 34 (3), 375-409.

Reed, K. K., Lubattkin, M. and Srinvasan, N. (2006). Proposing and testing an intellectual capital based view of the firm. Journal of Management Studies, 43(4), 867-894.

Rothwell, R. (1975). Intracorporate entrepreneurs. Management Decision, 13 (3), 142-54.

Spender, J. C. (1996). Making knowledge the basis of dynamic theory of the firm. Strategic Management Journal, 17, Winter Special Issues, 45-62.

Subramaniam, M. and Youndt, M. A. (2005). The influence of intellectual capital on the types of innovative capabilities. Academy of Management Journal, 48, 450-463.

Taggar, S. (2002). Individual creativity and group ability to utilize individual creative resources: a multilevel model. Academy of Management Journal, 45, 315-330.

Zhou, K. Z. (2006). Innovation, imitation and new product performance: The case of China. Industrial Marketing Management, 35, 394-402. 